\title{
Suitability of Large Sized Compacted Baked Clay Blocks as a Walling Material
}

\author{
Nawab Ali Lakho, Muhammad Auchar Zardari* \\ Department of Civil Engineering, Quaid-e-Awam University of Engineering, Science and Technology, Nawabshah, Pakistan \\ Email: *muhammad.auchar@quest.edu.pk
}

How to cite this paper: Lakho, N.A. and Zardari, M.A. (2016) Suitability of Large Sized Compacted Baked Clay Blocks as a Walling Material. Engineering, 8, 669-675. http://dx.doi.org/10.4236/eng.2016.810060

Received: August 21, 2016

Accepted: October 7, 2016

Published: October 10, 2016

Copyright $\odot 2016$ by authors and Scientific Research Publishing Inc. This work is licensed under the Creative Commons Attribution International License (CC BY 4.0).

http://creativecommons.org/licenses/by/4.0/ (c) (i) Open Access

\begin{abstract}
Some disadvantages associated with conventional brick masonry are: high cost of construction, lower compressive strength and less durability. In order to resolve these problems, a new technique of constructing walls using large size baked clay blocks is introduced. For this purpose, clay blocks of size $150 \mathrm{~mm} \times 300 \mathrm{~mm} \times 1980$ $\mathrm{mm}$ were cast at a pressure of $6 \mathrm{MPa}$, and fired at a temperature of $700^{\circ} \mathrm{C}$. In this paper, compressive strength and tensile strength of baked clay were investigated in order to find its suitability as a walling material for low cost houses. Cubes of 150 $\mathrm{mm}$ sides were tested in compression and the beams were tested in flexure. The results showed that compressive strength of baked clay cubes was found to be $10 \mathrm{MPa}$ and tensile strength, in terms of modulus of rupture, was found to be $2.3 \mathrm{MPa}$. Since the baked clay blocks are larger in size than traditional bricks, it is inferred that the blocks could be used as a cheaper and stronger walling material.
\end{abstract}

\section{Keywords}

Baked Clay, Compressive Strength, Modulus of Rupture, Walling Material, Low Cost Houses

\section{Introduction}

Developing countries like Pakistan are experiencing more population growth and have limited resources to meet housing crisis for low income people. Main structural elements of a building are: footing, column, wall, beam and slab. Of these elements, walls require more than $50 \%$ of total material of building construction. Traditionally, baked clay bricks are used as a material of construction of walls. But, brick masonry has some drawbacks such as: 1) it requires more quantity of cement mortar, plastering material and more labour cost, and 2) compressive strength of a masonry wall is generally less as compared to that of individual bricks. 
Compressive strength of baked clay is dependent upon compaction at the time of casting [1], and firing temperature [2]-[4]. But, the bricks are generally cast without compaction and are fired at $1000^{\circ} \mathrm{C}$ in a kiln. Firing of bricks at this temperature requires more fuel, resulting in the increase of the cost. The cost of mortar and labour incurred in brick masonry may be reduced if large baked clay blocks of uniform size are used instead of bricks. Generally, cost of fuel used for firing commercial baked clay bricks is considered to be major part of the total cost of manufacturing. In addition, the cost of firing could be reduced by compacting the clay blocks and baking them at relatively less temperature. If the width of clay blocks is kept equal to that of a masonry wall, there may be no need of plastering and colouring. Moreover, these compacted baked clay blocks may be used as lintels over small openings of doors and windows. If the span of an opening is more, then these baked clay blocks can also be reinforced before using as lintels. Therefore, besides compressive strength, tensile strength in terms of modulus of rupture of baked clay blocks is required to be investigated.

Previous studies have been conducted to explore potential of baked clay beams as a substitute of Reinforced Cement Concrete, see e.g., references [5]-[12]. Compressive strength as high as $38 \mathrm{MPa}$, was achieved when these clay blocks compacted at $7.2 \mathrm{MPa}$ were fired at the temperature of $1000^{\circ} \mathrm{C}[1]$. The average compressive strength of fired bricks manufactured in Sindh, Pakistan is about $12 \mathrm{MPa}$ [13]. In general, the compressive strength of masonry is about one-fourth of an individual brick [14]. The object of this study is to investigate suitability of baked clay blocks fired at a temperature of $700^{\circ} \mathrm{C}$ to be used as a walling material instead of traditional brick masonry. No such study is reported in the literature.

\section{Materials and Methods}

\subsection{Casting of Baked Clay Blocks}

Indigenous clay and pit sand were mixed in a ratio of 70:30 by weight. Twenty-two percentage of potable water was added in the mixture which was mixed well in a pan mixer for fifteen minutes. This moist mixture was covered with plastic sheet. Clay blocks of size $150 \mathrm{~mm} \times 300 \mathrm{~mm} \times 1980 \mathrm{~mm}$ were cast in a steel mould. The blocks were cast in five equal layers. Each layer was tamped and spray of water was applied to achieve bond between consecutive layers. The blocks were compacted, at a pressure of 6 MPa, with the help of wooden plunger of the Mechanized System (Figure 1). The details of the Mechanized System can be found in the reference [15] written by the authors.

These blocks were demoulded after casting and allowed to dry in shade. During, the process of drying, these beams were covered in a plastic sheet to control the rate of evaporation in order to reduce the possibility of cracking and warping. After drying in shade, the clay blocks were sun-dried for two days. These sun-dried clay blocks were fired in a potter's kiln present in the laboratory. The temperature of firing chamber of the kiln was checked with the help of thermocouple. The temperature of the kiln was increased slowly to $200^{\circ} \mathrm{C}$ and then it was maintained for six hours. Then the tempera- 
ture was increased in increments, each of $50^{\circ} \mathrm{C}$. Each increment of the temperature was maintained for half an hour. Finally, the temperature was increased to $700^{\circ} \mathrm{C}$ and maintained for three hours. During whole process of firing, the lid of the kiln was slightly opened in order to allow the steam and moist flue gases to escape. Then, the firing was stopped and the blocks were allowed to cool slowly. Figure 2 shows a baked a clay block after firing.

\subsection{Testing Programme}

Cubes having standard size of $150 \mathrm{~mm}$ [16] were cut from these baked clay blocks and tested for compression in Universal Testing Machine as shown in Figure 3. The beam prisms having size of $150 \mathrm{~mm} \times 150 \mathrm{~mm} \times 760 \mathrm{~mm}$ were also sawed from the baked clay blocks. These beam prisms were tested in flexure in accordance with ASTM C42M [17] and ASTM C293M [18]. The beams were supported on rollers at the ends and load was applied at mid span (Figure 4). The effective span of the beam during test was 600 $\mathrm{mm}$. The modulus of rupture was calculated by using the following relation [18]:

$$
R=1.5 P L / b d^{2}
$$

where $R$ is the modulus of rupture in $\mathrm{MPa}, P$ is the maximum applied load in Newton, $L$ is the span length in $\mathrm{mm}, b$ and $d$ are the average width, and depth of the specimen in $\mathrm{mm}$, respectively.

In order to compare modulus of rupture of baked clay with concrete, following formula was used [18]:

$$
f_{r}=7.5 \sqrt{f_{c}}
$$

where $\sqrt{f_{c}}$ is the compressive strength of in psi.

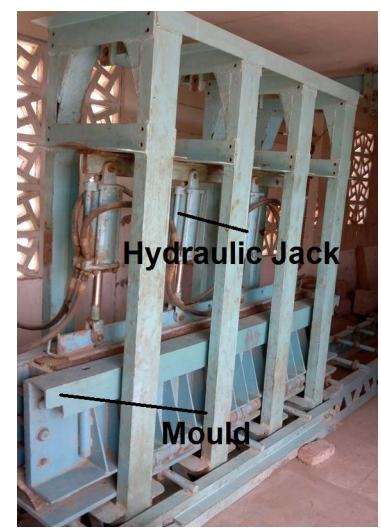

Figure 1. Mechanized system for compaction of clay beams.

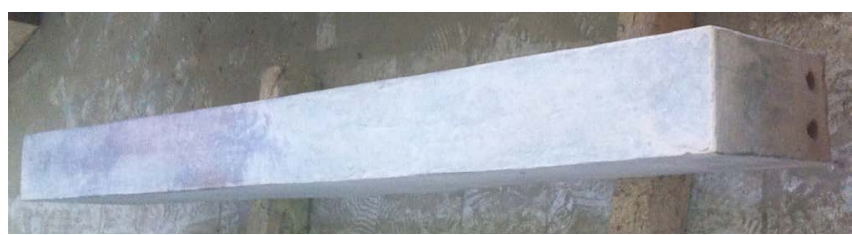

Figure 2. A view of a baked clay block after firing. 


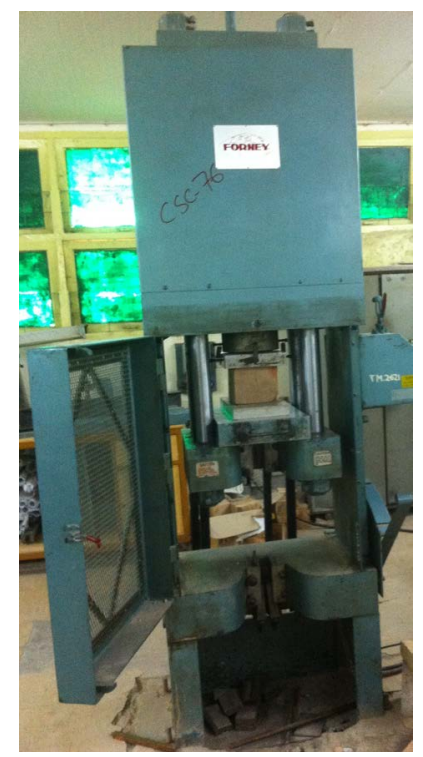

Figure 3. Compressive strength test is being performed on a baked clay cube of $150 \mathrm{~mm}$ size, using universal testing machine.

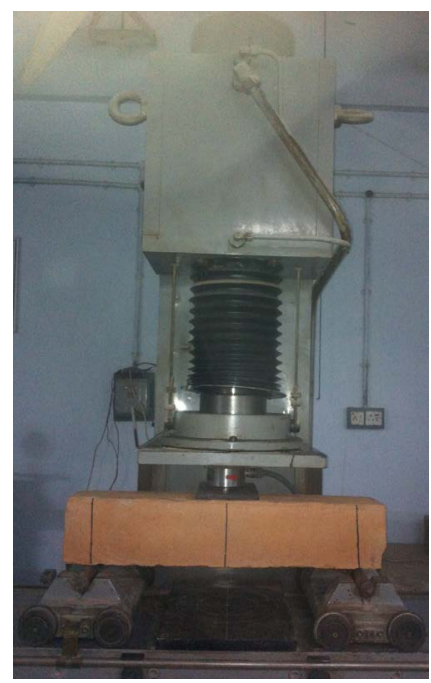

Figure 4. A plain baked clay beam is being tested for modulus of rupture in universal beam testing machine.

\section{Results and Discussions}

\subsection{Compressive Strength of Baked Clay Cubes}

Five cubes of $150 \mathrm{~mm}$ size were tested in Universal Testing Machine. The average compressive strength of the cubes was found to be about $10 \mathrm{MPa}$. As mentioned in the introduction that the compressive strength of brick masonry used locally in the region where this study was conducted is about $3 \mathrm{MPa}$. If large baked clay blocks as described in this paper are to be used as a walling material, compressive strength of the wall may not decrease to the magnitude exhibited by the brick masonry. This is because, the size of the baked clay blocks is very large as compared to a traditional brick, resulting in less 
mortar joints and improved compressive strength. This implies that the use of large sized compacted baked clay blocks as a walling material may result in strong and economical construction of houses.

\subsection{Modulus of Rupture}

Beam prisms having size of $150 \mathrm{~mm} \times 150 \mathrm{~mm} \times 760 \mathrm{~mm}$ were sawed from these compacted baked clay blocks. These beams were tested with single point load applied at mid span. The beams were simply supported at their ends during the test. The results of the above plain baked clay beams tested in flexure are presented in Table 1. The average value of modulus of rupture of baked clay beams was found to be $2.3 \mathrm{MPa}$. The value of modulus of rupture, according to ACI code ACI 318-11 [19] for normal weight concrete, is $3 \mathrm{MPa}$. Thus, the average value of modulus of rupture of baked clay beams fired at $700^{\circ} \mathrm{C}$ is about $75 \%$ of the corresponding value of the normal weight concrete. The modulus of rupture depends upon compressive strength of a material. As stated above, the compressive strength of baked clay can be improved by the application of compaction at the time of casting [1]. Since the modulus of rupture of normal weight concrete is usually taken as $15 \%$ of its compressive strength. However, the tensile strength exhibited by concrete is not taken into consideration in design. Generally, steel bars are provided to make concrete stronger in tension. It can be concluded that like concrete, the tensile strength of the baked clay fired at $700^{\circ} \mathrm{C}$ can be improved by using reinforcement.

\section{Conclusions}

In this paper, it was investigated whether large baked clay blocks could be used as walling material instead of brick masonry. The following conclusions can be drawn:

1) The average cube crushing strength of the baked clay, compacted at $6 \mathrm{MPa}$ and fired at $700^{\circ} \mathrm{C}$, was found to be $10 \mathrm{MPa}$.

2) The average value of the modulus of rupture of baked clay beams was found to be 2.3 MPa, which is about $75 \%$ of the corresponding value of the normal weight concrete.

3) This study suggests that the compacted baked clay blocks could serve as an economical and stronger walling material as compared to brick masonry.

\section{Acknowledgements}

The authors would like to thank Quaid-e-Awam University of Engineering, Science and

Table 1. Load at failure and modulus of rupture of plain baked clay beams.

\begin{tabular}{ccc}
\hline Beam ID & Load at failure (N) & Modulus of rupture (MPa) \\
\hline PBCB1 & 7500 & 2.0 \\
PBCB2 & 7875 & 2.1 \\
PBCB3 & 8250 & 2.2 \\
PBCB4 & 7875 & 2.1 \\
\hline
\end{tabular}


Technology Nawabshah, for providing access to the Structural Engineering Laboratory to conduct the tests mentioned in this study.

\section{References}

[1] Lakho, N.A., Zardari, M.A. and Memon, F.A. (2016) Effect of Intensity of Compaction on Crushing Strength of Indigenous Baked Clay. Journal of Engineering Research, 4, 18-28. http://dx.doi.org/10.7603/s40632-016-0011-5

[2] Karaman, S., Ersahin, S. and Gunal, H. (2006) Firing Temperature and Firing Time Influence on Mechanical and Physical Properties of Clay Bricks. Journal of Scientific and Industrial Research, 65, 153-159.

[3] Karaman, S., Gunal, H. and Ersahin, S. (2006) Assessment of Clay Bricks Compressive Strength Using Quantitative Values of Colour Components. Construction and Building Materials, 20, 348-354. http://dx.doi.org/10.1016/j.conbuildmat.2004.11.003

[4] Johari, I., Said, S., Hisham, B., Bakar, A. and Ahmad, Z.A. (2010) Effect of the Change of Firing Temperature on Microstructure and Physical Properties of Clay Bricks from Beruas (Malaysia). Science of Sintering, 42, 245-254. http://dx.doi.org/10.2298/SOS1002245I

[5] Ansari, A.A., Bhatti, N.K. and Bhutto, A. (2013) Suitability of Pre-Perforated Post-Reinforced Baked Clay Beam Panels for Low Cost Housing. American Journal of Civil Engineering, 1, 6-15. http://dx.doi.org/10.11648/j.ajce.20130101.12

[6] Ansari, A.A. and Lakho, N.A. (2013) Determination of Structural Properties of Baked Clay as Replacement of RCC. International Journal of Emerging Technology and Advanced Engineering, 3, 17-25.

[7] Ansari, A.A. (2008) Experimental Study of the Behaviour of Pre-Perforated Post-Reinforced Baked Clay Panels of Beams. Ph.D. Thesis, Quaid-e-Awam University of Engineering Science and Technology, Nawabshah.

[8] Lakho, N.A. and Zardari, M.A. (2016) Comparison of Compressive and Tensile Strength of Baked Clay with Those of Normal Concrete. Engineering, 8, 301-307. http://dx.doi.org/10.4236/eng.2016.86027

[9] Lakho, N.A. and Zardari, M.A. (2016) Flexural Behaviour of Reinforced Baked Clay Beams. Engineering, 8, 403-409. http://dx.doi.org/10.4236/eng.2016.87037

[10] Lakho, N.A. and Zardari, M.A. (2016) Experimental Study of Flexural Behaviour of Reinforced Baked Clay Beams under Impact Loading. Engineering, 8, 347-352. http://dx.doi.org/10.4236/eng.2016.86032

[11] Lakho, N.A., Zardari, M.A. and Memon, N.A. (2016) Effect of Firing on Cracking and Warping of Clay Beams. Mehran University Research Journal of Engineering and Technology, 35, 247-252.

[12] Lakho, N.A., Zardari, M.A. and Memon, N.A. (2015) Reduction of Cracking and Shrinkage in Compressed Clay Beams during Drying. Mehran University Research Journal of Engineering and Technology, 35, 395-400.

[13] Khoso, S., Wagan, F., Khan, J., Bhatti, N. and Ansari, A. (2014). Qualitative Analysis of Baked Clay Bricks Available in Larkana Region, Pakistan. Architecture Civil Engineering Environment, 7, 41-50.

[14] Kaushik, H.B., Rai, D.C. and Jain, S.K (2007) Stress-Strain Characteristics of Clay Brick Masonry under Uniaxial Compression. Journal of materials in Civil Engineering, 19, 728739. http://dx.doi.org/10.1061/(ASCE)0899-1561(2007)19:9(728)

[15] Lakho, N.A., Zardari, M.A., Memon, M. and Saand, A. (2015) Design and Fabrication of 
Mechanized System for Casting and Compacting Laboratory Size Clay Beams. Scientiairanica, 22, 2046-2051.

[16] BS EN 12390-3 (2002) Testing Hardened Concrete-Part 3: Compressive Strength of Test Specimens.

[17] ASTM C42M-13 (2013) Standard Test Method for Obtaining and Testing Drilled Cores and Sawed Beams of Concrete. ASTM International, West Conshohocken, PA.

[18] ASTM C293M-10 (2010) Standard Test Method for Flexural Strength of Concrete (Using Simple Beam with Center-Point Loading. ASTM International, West Conshohocken, PA.

[19] ACI 318-11 (2011) Building Code Requirements for Structural Concrete. American Concrete Institute, Farmington Hills, MI.

Submit or recommend next manuscript to SCIRP and we will provide best service for you:

Accepting pre-submission inquiries through Email, Facebook, LinkedIn, Twitter, etc. A wide selection of journals (inclusive of 9 subjects, more than 200 journals)

Providing 24-hour high-quality service

User-friendly online submission system

Fair and swift peer-review system

Efficient typesetting and proofreading procedure

Display of the result of downloads and visits, as well as the number of cited articles Maximum dissemination of your research work

Submit your manuscript at: http://papersubmission.scirp.org/

Or contact eng@scirp.org 